\title{
RESPONS PERTUMBUHAN DAN KERAGAAN DARAH DARI TIGA STRAIN IKAN NILA TERHADAP PEMBERIAN HORMON PERTUMBUHAN REKOMBINAN IKAN KERAPU KERTANG
}

\author{
Nunuk Listiyowati" \#, Alimuddin" ${ }^{(* *)}$, Sukenda"), dan Priadi Setyawan") \\ ") Balai Penelitian Pemuliaan Ikan \\ Departemen Akuakultur, Institut Pertanian Bogor
}

(Naskah diterima: 29 September 2015; Revisi final: 3 November 2015; Disetujui publikasi: 9 November 2015)

\begin{abstract}
ABSTRAK
Berbagai strain ikan nila sudah berhasil dibudidayakan di Indonesia. Penelitian ini dilakukan untuk mengevaluasi penambahan hormon pertumbuhan rekombinan ikan kerapu kertang, Epinephelus lanceolatus (rElGH) dalam pakan terhadap performa pertumbuhan dan imunitas tiga strain ikan nila terhadap infeksi bakteri Streptococcus agalactiae. Tiga strain nila yang digunakan adalah strain nila biru (hasil pemuliaan di Sukamandi), srikandi (toleran salinitas tinggi dari Sukamandi) dan nirwana (hasil pemuliaan di Wanayasa)dengan kisaran rerata bobot 0,24-0,4 g/ekor dan panjang standar 1,9-2,27 cm/ekor. Ikan dipelihara dalam bak fiber bulat kapasitas 1,5 ton air sebanyak sembilan buah selama 50 hari, dengan padat tebar 200 ekor/bak. Pakan mengandung rElGH dosis $2 \mathrm{mg} / \mathrm{kg}$ pakan diberikan dua hari sekali, selama dua minggu dengan frekuensi tiga kali sehari (pagi, siang, dan sore) secara at satiation (sampai kenyang). Hasil penelitian menunjukkan ikan yang diberi rElGH memiliki pertumbuhan yang lebih baik dibandingkan kontrol, kecuali nila biru. Pertumbuhan terbaik terdapat pada nila srikandi dengan bobot 6,08 $\pm 1,26 \mathrm{~g}$; laju pertumbuhan harian $0,12 \pm 0,03 \mathrm{~g} /$ hari dan panjang standar 5,5 $\pm 0,63 \mathrm{~cm}$. Ikan nila yang mendapatkan perlakuan rElGH pada pakan menunjukkan ketahanan tubuh yang berbeda ketika diuji tantang dengan bakteri S. agalactiae. Ikan nila nirwana memiliki jumlah kematian yang paling sedikit $(\mathrm{P}<0,05)$ dibandingkan dengan ikan nila srikandi dan nila biru terhadap infeksi S. agalactiae. Nilai MTD ikan nila nirwana perlakuan rElGH dan kontrol adalah 174,3 jam dan 217,7 jam. Hasil pengamatan uji tantang menunjukkan bahwa tidak ada yang berbeda dalam parameter hematologi. Sebagai kesimpulan, strain ikan nila sangat memengaruhi efektivitas pemberian rElGH dalam memacu pertumbuhan dan imunitasnya.
\end{abstract}

KATAKUNCI: pertumbuhan, imunitas, hormon pertumbuhan rekombinan ikan kerapu kertang (rElGH), Streptococcus agalactiae, ikan nila

ABSTRACT: Growth and haematology performance response of three tilapia strains fed on diet containing a recombinant giant grouper growth hormone. By: Nunuk Listiyowati, Alimuddin, Sukenda, and Priadi Setyawan

Various strains of tilapia has been successfully cultivated in Indonesia. This study was aimed to evaluate the effect of recombinant Epinephelus lanceolatus growth hormone (rElGH) supplementation in diet on growth performance and immunity of three strains of tilapia against Streptococcus agalactiae infection. Three strains of tilapia used were blue tilapia (breeding from Sukamandi), Srikandi (tolerant of high salinity of Sukamandi), and Nirwana (breeding from Wanayasa) with the range of mean weight of 0.24-0.4 g/fish and standard length 1.9-2.27 cm/fish. The fish were maintenanced in nine fiber tanks of 1.5 tons volume, with stocking density 200 fish/tank for 50 days. Feed containing rElGH (2 mg/kg) was given twice a day, for two weeks with a frequency of three times a day (morning, afternoon, and evening) at satiation. The results showed that the rElGH treated fish had better growth than that of the control fish, except for the blue tilapia strain. The best growth was found in Srikandi strain with the weight gain of $6.08 \pm 1.26$ $\mathrm{g}$, daily growth rate $0.12 \pm 0.03 \mathrm{~g} / \mathrm{d}$ and length gain $5.5 \pm 0.63 \mathrm{~cm}$. Fish treated with $\mathrm{rElGH}$ showed a different resistance to $S$. agalactiae infection. Nirwana strain has the lowest number of deaths $(P<0.05)$. MTD value of rElGH-

\# Korespondensi: Balai Penelitian Pemuliaan Ikan. Jl. Raya 2

Pantura Sukamandi, Patokbeusi, Subang 41263, Jawa Barat,

Indonesia. Tel.: + (0260) 520662

E-mail: nurul_maisaroh@yahoo.com 
treated Nirwana and control fish was $174.3 \%$ and $217.7 \%$ respectively. The challenge test result showed that there were no different in haematology parameters. As conclusion, tilapia strains greatly affected the effectiveness of $r E I G H$ in increasing growth and immunity.

KEYWORDS: $\quad$ growth, immunity, recombinant Epinephelus lanceolatus growth hormone (rElGH), Streptococcus agalactiae, tilapia

\section{PENDAHULUAN}

Ikan nila Oreochromis niloticus merupakan komoditas budidaya andalan di Indonesia dan dunia dengan produksi global sebesar 4,85 juta ton pada tahun 2014 . Data statistik FAO tahun 2014 menunjukkan bahwa Indonesia sebagai produsen ikan nila terbesar ketiga di dunia setelah Cina dan Mesir. Pengembangan dan penerapan teknologi untuk meningkatkan efisiensi produksi ikan nila telah banyak dilakukan, terutama yang berkaitan dengan upaya peningkatan pertumbuhan, meliputi teknologi budidaya, pakan, dan rekayasa genetika. Salah satu teknologi alternatif yang dapat dan aman untuk dilakukan adalah penggunaan protein hormon pertumbuhan rekombinan (recombinant growth hormone, rGH) ikan dalam memacu pertumbuhan.

Efektivitas pemberian rGH dalam meningkatkan pertumbuhan tergantung pada jenis $\mathrm{rGH}$, dosis, umur, dan jenis ikan uji yang digunakan (Hertz et al., 1991). Tingkat produksi dalam pembuatan rGH ikan kerapu kertang Epinephelus lanceolatus ( $\mathrm{r} E l \mathrm{GH}$ ) lebih tinggi dibandingkan rGH ikan mas Cyprinus carpio $(\mathrm{rCcGH})$ dan rGH ikan gurami Osphronemus gouramy (rOgGH). Beberapa penelitian telah mampu membuktikan kemampuan rElGH dalam meningkatkan pertumbuhan ikan target, sebagaimana telah dilakukan oleh Handoyo et al. (2012) pada ikan sidat, Hardiantho et al. (2012) dan Muhammad (2014) pada ikan nila, Putra (2010), dan Safir (2012) pada ikan gurame.

Peningkatan produksi ikan nila dalam beberapa tahun terakhir disebabkan antara lain melalui intensifikasi budidaya. Tingkat kepadatan yang tinggi menyebabkan ikan lebih rentan terhadap stres dan penyakit (Iwana \& Nakanishi 1996). Bakteri pada umumnya berhubungan dengan berbagai macam penyakit, yang menyebabkan kematian dan kerugian pada budidaya ikan (Inglis et al., 1993; Plumb, 1999; Yin, 2004). Penyakit streptococcus, streptococcosis atau streptococciasis pada ikan, yang disebabkan oleh bakteri S. iniae dan S. agalactiae merupakan salah satu penyakit bakterial yang menginfeksi ikan yang ada di alam atau ikan budidaya baik pada lingkungan air tawar, payau maupun laut. Streptococcosis dapat menyebabkan kerugian besar bagi pembudidaya ikan intensif, dengan tingkat kematian ikan $>50 \%$ dalam waktu lebih dari satu minggu (Inglis et al., 1993; Yanong \& Francis-Floyd, 2006).
Studi tentang hubungan antara pemberian $\mathrm{rGH}$ dengan peningkatan kapasitas sistem imun telah dilakukan oleh Acosta et al. (2008) yang menunjukkan adanya peningkatan respons imunitas bawaan pada larva ikan nila yang direndam dengan recombinant truncated tGH. Pengujian hormon pertumbuhan rekombinan ikan kerapu kertang ( $\mathrm{r} E \mathrm{GH}$ ) dalam pakan untuk memacu pertumbuhan ikan dan peningkatan sistem kekebalan tubuh atau imunitas ikan sudah dilakukan pada udang vaname Litopenaeus vannamei (Subaidah, 2012) dan kerapu bebek Cromileptes altivelis (Antoro, 2014). Penelitian tentang pemberian $\mathrm{rElGH}$ dalam peningkatan imunitas untuk melawan infeksi streptococcosis pada ikan nila perlu dilakukan untuk mendukung peningkatan produksi ikan nila. Penelitian ini dilakukan untuk mengetahui efektivitas $\mathrm{rElGH}$ dalam memacu pertumbuhan dan imunitas pada tiga strain ikan nila.

\section{BAHAN DAN METODE}

Penelitian ini dilakukan pada bulan Januari 2013 sampai Agustus 2014 bertempat di Hatchery dan Laboratorium Genetika, Balai Penelitian Pemuliaan Ikan, Sukamandi.

\section{Uji Pertumbuhan}

Penelitian ini terdiri atas dua tahap. Pada tahap pertama, yaitu uji pertumbuhan yang dilakukan pada bak fiber bulat dengan kapasitas air 1,5 ton yang diisi $1.000 \mathrm{~L}$ air sebanyak sembilan buah (enam bak perlakuan dan tiga bak kontrol). Bak fiber didesinfeksi dan dilengkapi dengan aerasi sebanyak dua titik per bak.

Perlakuan yang digunakan dalam penelitian ini adalah (A) ikan nila biru, pakan rElGH $\rightarrow$ diuji tantang penyakit; (B) ikan nila biru, pakan non-rElGH $\rightarrow$ diuji tantang penyakit; (C) ikan nila srikandi, pakan $\mathrm{rElGH} \rightarrow$ diuji tantang penyakit; (D) ikan nila srikandi, pakan non$\mathrm{r} E I \mathrm{GH} \rightarrow$ diuji tantang penyakit; (E) ikan nila nirwana, pakan $\mathrm{r} E l \mathrm{GH} \rightarrow$ diuji tantang penyakit; (F) ikan nila nirwana, pakan non-rElGH $\rightarrow$ diuji tantang penyakit.

Hewan uji yang digunakan pada penelitian ini memiliki rerata bobot $0,32 \pm 0,14 \mathrm{~g} /$ ekor dan panjang $2,1 \pm 0,32 \mathrm{~cm} /$ ekor; benih ikan nila ditebar dengan kepadatan 200 ekor/bak.

Pembuatan pakan uji dilakukan dengan mencampurkan pakan komersial berkadar protein $40 \%$ 
dengan penambahan rElGH dosis $2 \mathrm{mg} / \mathrm{kg}$ yang sudah dilarutkan dalam 15 mL PBS dicampur dengan $2 \mathrm{mg}$ kuning telur ayam untuk $100 \mathrm{~g}$ pakan (Hardiantho et al., 2012). Pakan mengandung rElGH diberikan dua hari sekali, selama dua minggu dengan frekuensi tiga kali sehari (pagi, siang, dan sore) secara at satiation (sampai kenyang). Penyiponan dan pergantian air sebanyak 25\%-50\% dilakukan dua kali per minggu untuk menjaga kestabilan kualitas air.

Efektivitas pemberian rElGH ditentukan berdasarkan pertambahan bobot rata-rata (DW), laju pertumbuhan harian (LPH), dan sintasan. Bobot dan panjang badan semua sampel ikan diukur setiap sepuluh hari sekali. LPH dan DW berturut-turut dihitung menggunakan rumus: $\mathrm{LPH}=(\mathrm{Wt}-\mathrm{Wo}) \times 100$ / $\mathrm{t}$; dan DW = Wt-Wo. Wt, Wo, dan t, masing-masing adalah bobot akhir (g), bobot awal (g), dan t waktu (hari). Sintasan dihitung pada akhir pemeliharaan berdasarkan Zonneveld et al. (1991).

\section{Analisis Proksimat}

Analisis proksimat dilakukan setelah akhir pemeliharaan untuk mengetahui kandungan nutrien ikan nila biru, Srikandi, dan Nirwana. Parameter protein, lemak, abu, dan BETN (Bahan Ekstrak Tanpa Nitrogen) diukur sesuai dengan metode analisis proksimat menurut Takeuchi (1988) pada sampel daging ikan sebanyak 10 ekor per strain.

\section{Uji Tantang Bakteri S. agalactiae}

Pada tahap kedua dilakukan uji tantang terhadap penyakit streptococcosis dengan menggunakan bakteri $S$. agalactiae tipe non-hemolitik $\left(\mathrm{NK}_{1}\right)$ yang berasal dari koleksi Laboratorium Kesehatan Ikan Balai Penelitian Perikanan Air Tawar, Bogor. Uji tantang pada setiap perlakuan diberi tiga kali pengulangan. Uji tantang dilakukan pada wadah akuarium (60 cm x 40 $\mathrm{cm}$ x $50 \mathrm{~cm}$ ) dengan padat tebar 20 ekor ikan. Masingmasing perlakuan diinjeksi dengan suspensi bakteri S. agalactiae tipe non-hemolitik $\left(\mathrm{NK}_{1}\right)$ dosis $10^{7} \mathrm{cfu} /$ $\mathrm{mL}\left(\mathrm{LD}_{50}\right.$ pada ikan Nirwana) sebanyak $0,1 \mathrm{~mL} / \mathrm{ekor}$ pada ikan nila biru, Srikandi, dan Nirwana hasil uji pertumbuhan. Sebagai kontrol negatif ikan diinjeksi dengan larutan phosphate buffer saline sebanyak 0,1 $\mathrm{mL} / \mathrm{ekor}$. Uji tantang penyakit dilakukan selama 30 hari.

Sintasan dihitung pada masa infeksi (dua minggu awal) dan masa recovery (dua minggu akhir). Pengamatan mean time to death (MTD) dilakukan untuk mengetahui rerata waktu kematian ikan uji yang terinfeksi S. agalactiae, dihitung menurut Kamiso (2001). Konfirmasi penyebab kematian ikan dilakukan dengan mengisolasi bakteri dari mata, otak, ginjal, dan hati, kemudian dikultur dalam media BHIA. Bakteri S. agalactiae memiliki ciri: koloni berwarna putih, bentuk bulat/coccus, dan berukuran kecil. Konfirmasi jenis bakteri dilakukan menggunakan uji katalase dan PCR. Analisis PCR dilakukan menggunakan primer Sdi61: aggaacctgccatttgcg, dan Sdi-252: caatctatttctagatcgtgg, dengan produk berukuran 192 bp (Mata et al., 2003). PCR dilakukan dengan program: pre-denaturasi $94^{\circ} \mathrm{C}$ selama dua menit; 30 siklus amplifikasi (denaturasi $94^{\circ} \mathrm{C}$ selama satu menit, annealing $30^{\circ} \mathrm{C}$ selama satu menit, dan extension $72^{\circ} \mathrm{C}$ selama 90 detik, serta final extension $4^{\circ} \mathrm{C}$ selama lima menit. Produk PCR diseparasi menggunakan gel agarose 1,5\%; dan divisualisasi dengan High Performance Ultraviolet Transilluminator (Gambar 1).

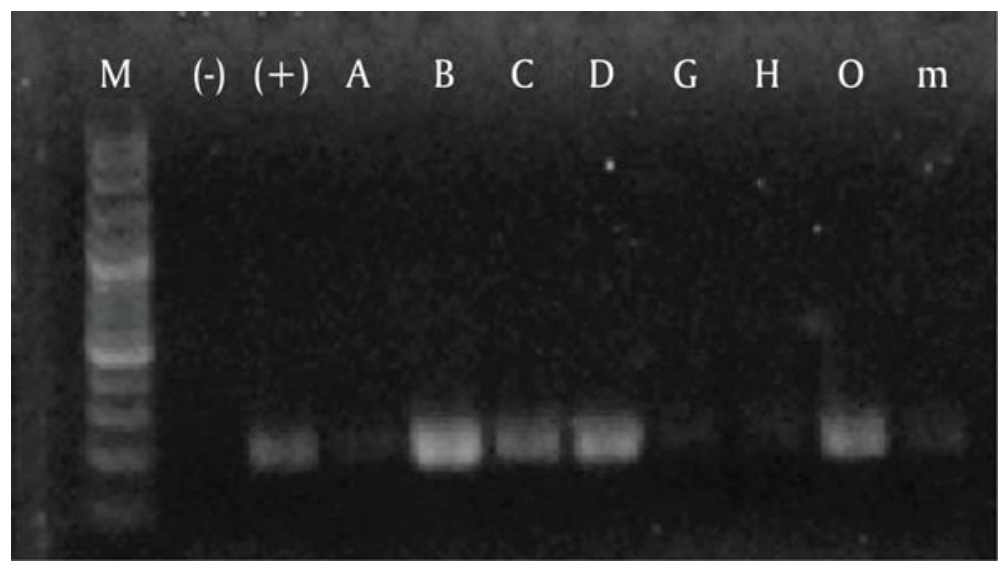

Keterangan: (M) marker 1 kB; (-) kontrol negatif; (+) kontrol positif; (A, B, C, D) sampel ikan nila uji tantang; $(\mathrm{G})$ ginjal; $(\mathrm{H})$ hati; $(\mathrm{O})$ otak; $(\mathrm{m})$ mata

Description: (M) marker $1 \mathrm{kB}$; (-) negative control; (+) positive control; $(A, B, C, D)$ tilapia challenge test samples; $(G)$ kidney; $(H)$ liver; $(O)$ brain; $(m)$ eye

Gambar 1. Hasil analisis PCR bakteri Streptococcus agalactiae

Figure1. PCR analysis result of Streptococcus agalactiae bacteria 
Pengamatan gambaran darah dilakukan setiap tiga hari sekali pada masa infeksi dan seminggu sekali pada masa recovery, sampel darah diambil dari daerah tulang ekor. Sementara, pengamatan keragaan darah meliputi: total eritrosit, total leukosit, dan hematokrit (Blaxhall \& Daisley, 1973), serta titer antibodi diukur menggunakan metode aglutinasi (Anderson, 1974).

\section{Analisis Data}

Data pertumbuhan dan kematian ikan dianalisis dengan one-way ANOVA $(\mathrm{P}<0,05)$, (data pertumbuhan pada masing-masing strain dianalisis dengan uji $\mathrm{T}$ ). Perbedaan signifikan antara perlakuan dianalisis dengan menggunakan uji Duncan, data gambaran darah dianalisis secara deskriptif.

\section{HASIL DAN BAHASAN}

\section{Pertumbuhan}

Ikan nila yang diberi rElGH memiliki pertumbuhan bobot rata-rata yang lebih baik dibandingkan dengan tanpa pemberian $\mathrm{r} E l \mathrm{GH}$, namun hasil tersebut tidak berbeda nyata $(\mathrm{P}>0,05)$ pada semua populasi ikan nila (Gambar 2). Hasil penelitian ini menunjukkan bahwa pertumbuhan ikan nila yang diberi $\mathrm{rElGH}$ sangat dipengaruhi oleh strain ikan nila yang digunakan (Gambar 3). Pemberian rElGH berpengaruh nyata terhadap peningkatan bobot badan pada ikan nila srikandi dibandingkan dengan kontrol $(\mathrm{P}<0,05)$, sedangkan pada ikan nila Nirwana pemberian $r E l G H$ tidak berpengaruh nyata terhadap peningkatan bobot badan dibandingkan kontrol $(\mathrm{P}>0,05)$.
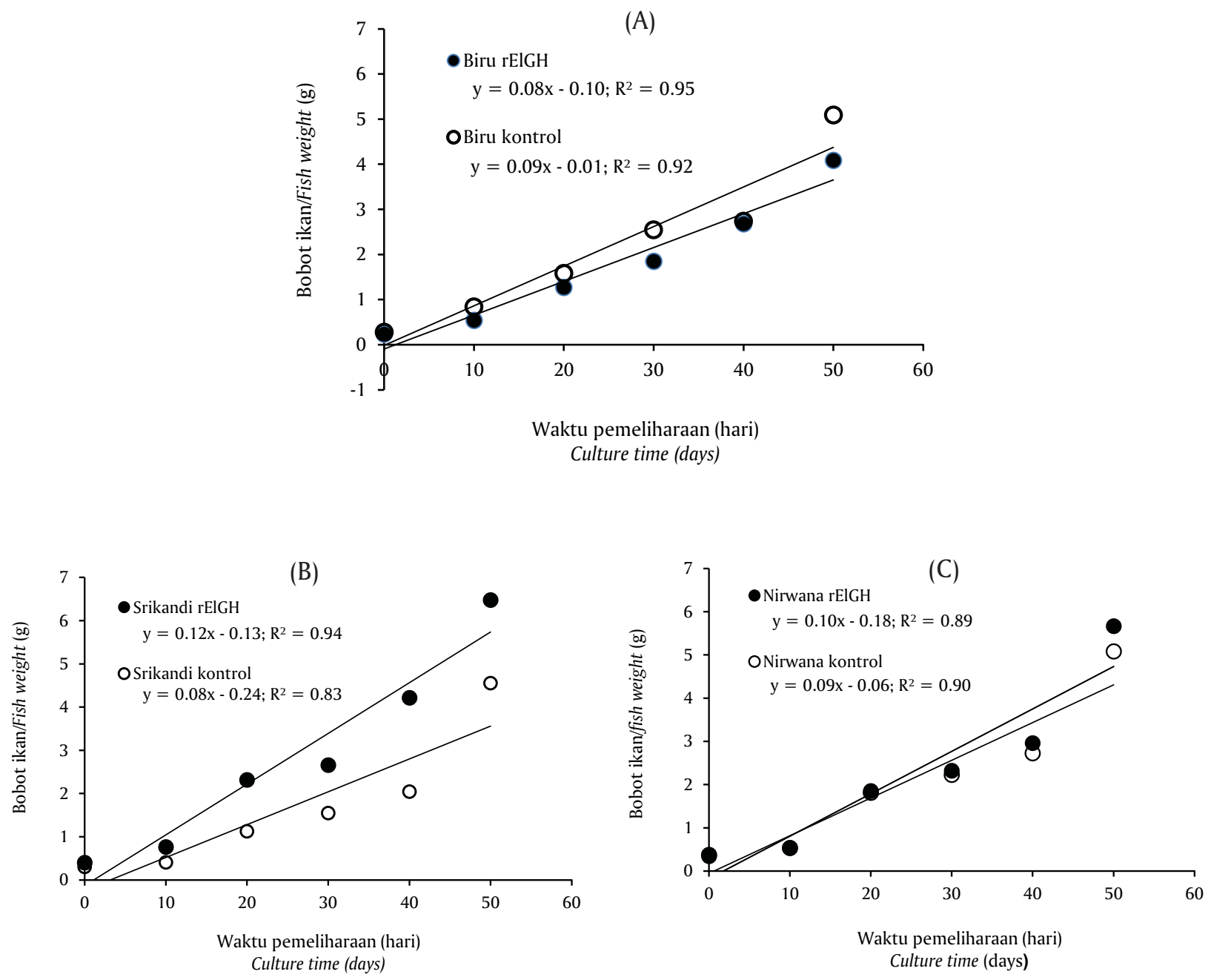

Gambar 2. Pertumbuhan bobot rata-rata ikan nila biru (A), ikan nila Srikandi (B), dan ikan nila Nirwana (C) yang diberi pakan mengandung rElGH (RGH) dan tanpa rElGH (kontrol); ikan dipelihara selama 50 hari

Figure 2. The average weight of blue (A), Srikandi (B), and Nirwana (C) tilapia which was given a diet containing rElGH and non-rElGH (control); fish were reared for 50 days 


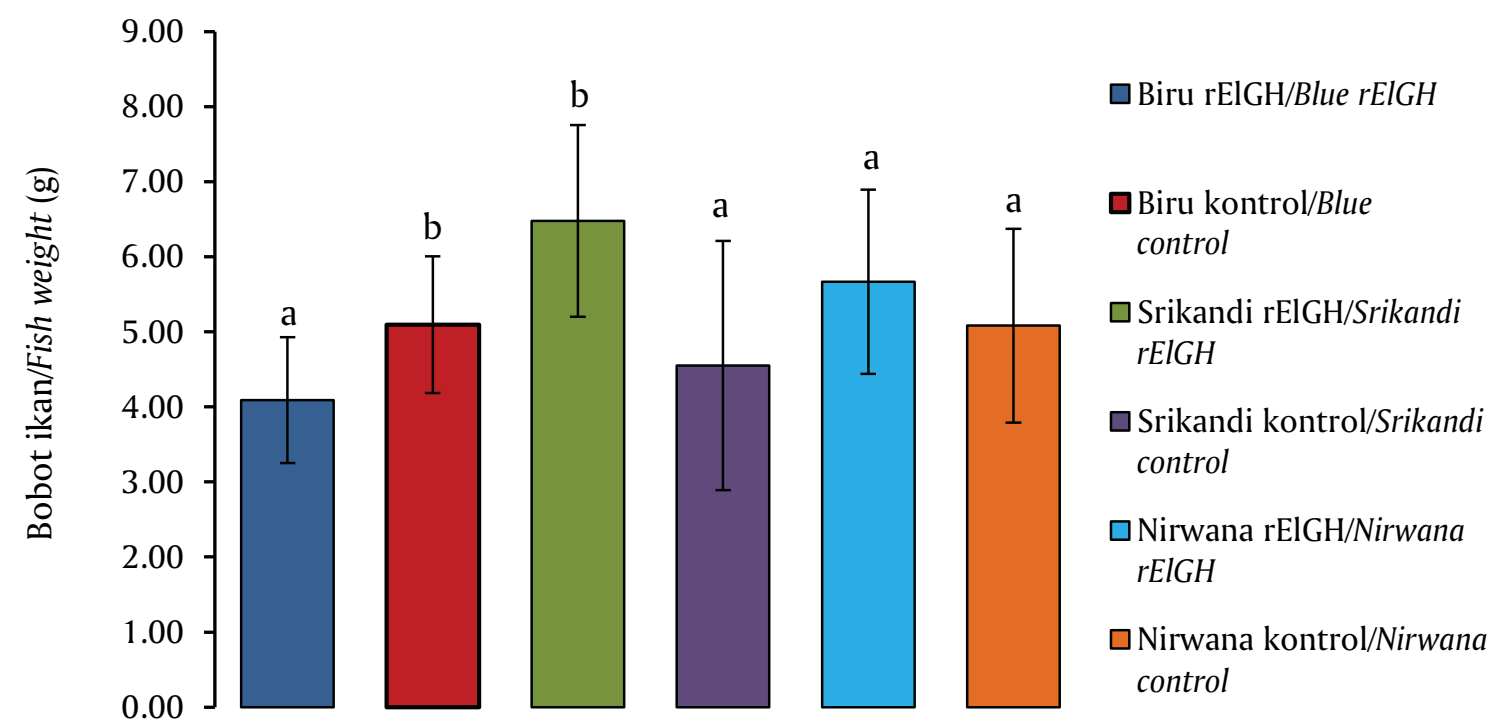

Populasi ikan uji

Treatments fish population

Gambar 3. Bobot ikan nila strain biru, Srikandi, dan Nirwana yang diberi pakan mengandung rElGH dan tanpa rElGH (kontrol). Data (mean $\pm \mathrm{SE}$ ) dengan huruf berbeda pada bar menunjukkan berbeda nyata antar perlakuan (uji T; $\mathrm{P}<0,05)$

Figure 3. The weight of blue, Srikandi, and Nirwana tilapia which was feed containing rEIGH and non-rElGH (control). Data (mean $\pm S E$ ) with different letters on the bar showed significantly different between treatments ( $t$ test; $P<0.05$ )

Pertumbuhan mutlak ikan nila Srikandi dan Nirwana yang diberi rElGH adalah lebih tinggi $(\mathrm{P}>0,05)$ sebesar 6,08 g dan 5,32 g (Tabel 1). Hasil ini selaras pula dengan nilai laju pertumbuhan hariannya yang dibandingkan dengan kontrolnya, masing-masing lebih tinggi dibandingkan kontrol. Berbeda dengan

Tabel 1. Pertumbuhan bobot mutlak, laju pertumbuhan harian, dan sintasan tiga strain ikan nila yang diberi pakan mengandung rElGH dan tanpa rElGH (kontrol)

Table 1. The growth of absolute weight, daily growth rate, and survival rate of three tilapia strains which was given feed containing rEIGH and non-rEIGH (control)

\begin{tabular}{lccccc}
\hline \multicolumn{1}{c}{$\begin{array}{c}\text { Populasi } \\
\text { Population }\end{array}$} & $\begin{array}{c}\text { Bobot awal } \\
\text { Initial weigth } \\
(\mathrm{g})\end{array}$ & $\begin{array}{c}\text { Bobot akhir } \\
\text { Final weigth } \\
(\mathrm{g})\end{array}$ & $\begin{array}{c}\text { Pertumbuhan mutlak } \\
\text { Absolute growth } \\
(\mathrm{g})\end{array}$ & $\begin{array}{c}\text { Pertumbuhan harian } \\
(\mathrm{g} / \text { hari) } \\
\text { Daily growth }(\mathrm{g} / \text { days })\end{array}$ & $\begin{array}{c}\text { Sintasan } \\
\text { Survival rate } \\
(\%)\end{array}$ \\
\hline $\begin{array}{l}\text { Nila biru rElGH } \\
\text { Blue tilapia rEIGH }\end{array}$ & $0.24 \pm 0.09$ & $4.09 \pm 0.84$ & $3.85 \pm 0.86^{\mathrm{b}}$ & $0.08 \pm 0.02^{\mathrm{b}}$ & 81.0 \\
$\begin{array}{l}\text { Nila biru kontrol } \\
\text { Blue tilapia control }\end{array}$ & $0.28 \pm 0.10$ & $5.09 \pm 0.91$ & $4.82 \pm 0.94^{\mathrm{b}}$ & $0.10 \pm 0.02^{\mathrm{b}}$ & 65.5 \\
$\begin{array}{l}\text { Nila Srikandi rElGH } \\
\text { Srikandi tilapia rEIGH }\end{array}$ & $0.40 \pm 0.12$ & $6.48 \pm 1.28$ & $6.08 \pm 1.26^{\mathrm{a}}$ & $0.12 \pm 0.03^{\mathrm{a}}$ & 84.0 \\
$\begin{array}{l}\text { Nila Srikandi kontrol } \\
\text { Srikandi tilapia control }\end{array}$ & $0.30 \pm 0.18$ & $4.55 \pm 1.66$ & $4.25 \pm 1.61^{\mathrm{a}}$ & $0.09 \pm 0.03^{\mathrm{a}}$ & 84.5 \\
$\begin{array}{l}\text { Nila Nirwana rEIGH } \\
\text { Nirwana tilapia rEIGH }\end{array}$ & $0.34 \pm 0.17$ & $5.67 \pm 1.23$ & $5.32 \pm 1.31^{\mathrm{a}}$ & $0.11 \pm 0.03^{\mathrm{a}}$ & 83.0 \\
$\begin{array}{l}\text { Nila Nirwana kontrol } \\
\text { Nirwana tilapia control }\end{array}$ & $0.37 \pm 0.18$ & $5.26 \pm 1.29$ & $4.89 \pm 1.30^{\mathrm{a}}$ & $0.10 \pm 0.03^{\mathrm{a}}$ & 78.0 \\
\hline
\end{tabular}

Keterangan: Data (mean \pm SE) dengan huruf berbeda menunjukkan berbeda nyata antar perlakuan strain $(\mathrm{DMR} ; \mathrm{P}<0,05)$ Description: Data (mean \pm SE) with different letters indicate significant difference among the treatments strain $(D M R ; P<0.05)$ 
kedua strain tersebut, pertumbuhan mutlak dan laju pertumbuhan harian ikan nila biru kontrol lebih tinggi $(\mathrm{P}>0,05)$ dibandingkan dengan yang diberi rElGH. Hal tersebut diduga sebagai akibat dari sintasan yang rendah (Tabel 2), dan kepadatan ikan lebih rendah sehingga pertumbuhan lebih tinggi daripada ikan perlakuan rElGH. Ikan nila srikandi yang diberi rElGH memiliki pertumbuhan mutlak dan LPH tertinggi, hal ini diduga karena ikan Srikandi merupakan hasil pemuliaan melalui jalur hibridisasi antara ikan nila Nirwana dan ikan nila biru (KEP.09/MEN/2012). Dengan demikian, respons pertumbuhan ikan nila Srikandi yang lebih tinggi daripada kedua strain lainnya diduga sebagai efek hibridisasi.

Pertumbuhan ikan nila berdasarkan nilai panjang standar (Gambar 4 dan 5) menunjukkan pola yang sama dengan pertumbuhan bobot badan. Nilai rerata panjang standar akhir tertinggi terdapat pada ikan nila Srikandi yang diberi rElGH $(5,5 \mathrm{~cm})$. Berdasarkan uji statistik, interaksi antara populasi ikan dengan rElGH memberikan pengaruh yang nyata $(\mathrm{P}<0,05)$, baik terhadap panjang standar maupun panjang total ikan pada waktu pemeliharaan 50 hari.

Efektivitas pemberian rElGH terhadap pertumbuhan ikan Nirwana tidak berbeda nyata $(\mathrm{P}>0,05)$ dibandingkan dengan kontrol, sedangkan ikan nila biru memberikan respons negatif terhadap pemberian rElGH dengan nilai respons relatif bobot sebesar $-19,72 \%$ dan panjang standar $-12,98 \%$. Hal tersebut menunjukkan bahwa kemungkinan besar reseptor $\mathrm{GH}$ ikan nila biru tidak sesuai dengan $\mathrm{GH}$ ikan kerapu kertang. Leedom et al. (2002) dan Jentoft
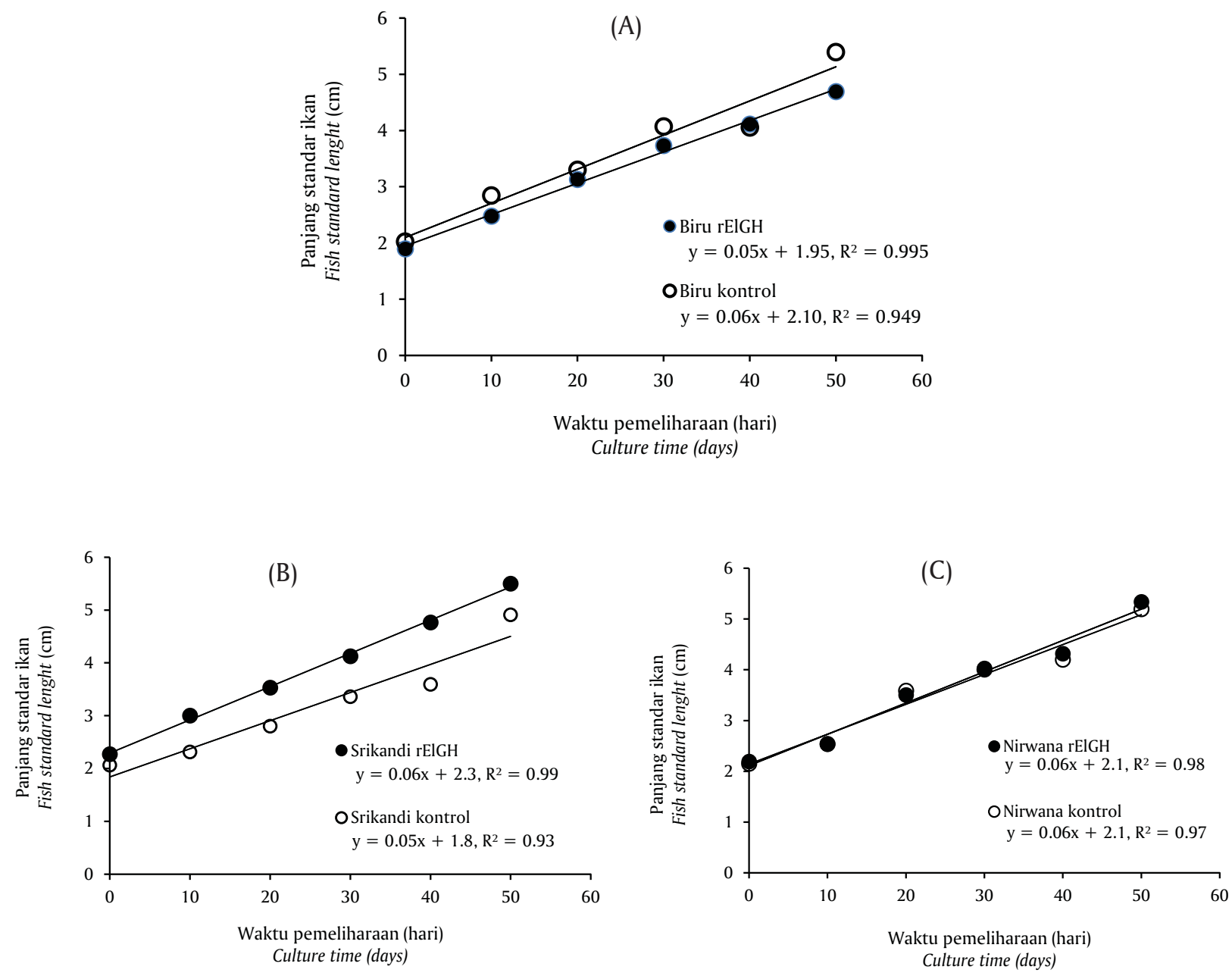

Gambar 4. Pertumbuhan panjang standar ( $\mathrm{cm}$ ) ikan nila biru (A), ikan nila Srikandi (B), dan ikan nila Nirwana (C) yang diberi pakan mengandung rElGH dan tanpa rElGH (kontrol); ikan dipelihara selama 50 hari

Figure 4. Growth of standard length (cm) of blue tilapia (A), Srikandi (B), and Nirwana (C) were given a diet containing rElGH and without rEIGH (control); fish reared for 50 days 


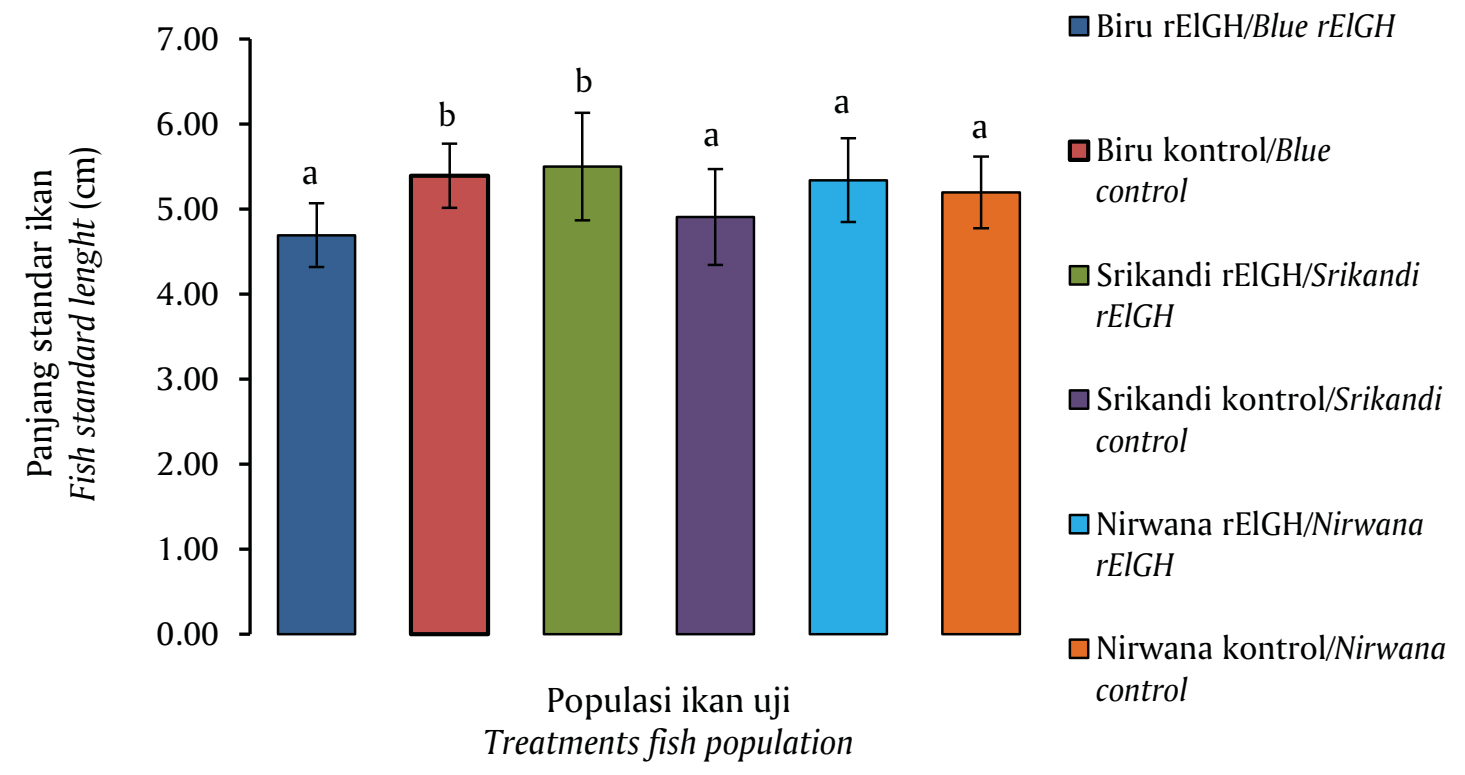

Gambar 5. Panjang standar $(\mathrm{cm})$ ikan nila strain biru, Srikandi, dan Nirwana yang diberi pakan mengandung $\mathrm{r} E l \mathrm{GH}$ dan tanpa $\mathrm{r} E \mathrm{GH}$ (kontrol). Data (mean $\pm \mathrm{SE}$ ) dengan huruf berbeda pada bar menunjukkan berbeda nyata antar perlakuan (uji T; $\mathrm{P}<0,05$ )

Figure 5. The standard length $(\mathrm{cm})$ strain of blue tilapia, Srikandi, and Nirwana are fed contains $r E I G H$ and non-rElGH (control). Data (mean $\pm S E$ ) with different letters on the bar showed significantly different between treatments ( t test; $P<0.05$ )

et al. (2005) mengatakan bahwa tidak adanya efek positif pemberian rbGH terhadap pertumbuhan ikan disebabkan karena rendahnya afinitas antara reseptor hormon organisme resipien dengan hormon eksogen. Respons terhadap rGH pada setiap jenis ikan berbedabeda. Le Bail et al. (1993) mengatakan bahwa spesies atau strain ikan yang lebih cepat tumbuh atau telah mengalami seleksi peningkatan pertumbuhan, mampu memproduksi GH endogen dan IGF yang lebih tinggi sehingga responsnya terhadap GH eksogen lebih rendah.

Ikan nila srikandi yang diberi tambahan rElGH dalam pakan menunjukkan pertumbuhan panjang dan bobot terbaik. Tingginya performa pertumbuhan pada ikan nila Srikandi merupakan salah satu keunggulan dari ikan hasil hibridisasi di mana persilangan antar strain merupakan salah satu cara untuk mendapatkan strain dengan keragaan budidaya yang meningkat. Berdasarkan keunggulan yang dimiliki sebagai ikan nila hibrida, maka pertumbuhan ikan nila srikandi dapat lebih dipacu dengan penambahan rElGH yang terbukti memberikan pengaruh positif pada pertumbuhannya. Muhammad (2014) menyatakan bahwa pemberian rElGH secara oral pada dosis 0,03 sampai $3,00 \mathrm{mg} / \mathrm{kg}$ pakan memberikan respons pertumbuhan yang sama $(\mathrm{P}>0,05)$ dan dapat meningkatkan pertumbuhan sebesar $24,07 \%$ sampai $31,68 \%$; dan pada fase pembesaran diketahui nila Srikandi memiliki laju pertumbuhan spesifik sebesar 3,36\%. Hasil penelitian ini menunjukkan ikan nila srikandi memberikan respons positif terhadap pemberian rElGH pada pakan dengan nilai respons relatif pertumbuhan bobot sebesar $42,26 \%$ dan panjang standar sebesar $12,10 \%$. Berdasarkan uji $\mathrm{T}$ hasil tersebut berbeda nyata dibandingkan dengan Srikandi kontrol $(\mathrm{P}<0,05)$. Peningkatan tersebut disebabkan karena hormon rGH yang diberikan melalui pakan ini diduga dapat diterima oleh reseptor dalam tubuh sehingga memberikan pengaruh yang terjadi melalui mekanisme secara langsung. Efektivitas pemberian rElGH pada ikan nila juga dilaporkan oleh Hardiantho et al. (2012) bahwa pemberian rGH ikan kerapu kertang lebih efektif dan efisien sehingga dapat diturunkan 10 dan 100 kali lebih rendah dibandingkan dengan rGH ikan mas yang diberikan pada ikan nila.

Berdasarkan hasil penelitian diperoleh peningkatan nilai sintasan ketiga strain ikan nila yang diberi pakan tambahan rElGH dibandingkan dengan ikan nila biru kontrol yaitu nila biru $(23,66 \%)$, Srikandi $(28,24 \%)$, dan Nirwana $(26,72 \%)$. Peningkatan sintasan pada ikan yang diberi perlakuan rElGH membuktikan bahwa rGH mampu meningkatkan kekebalan tubuh/imunitas pada ikan dari stres akibat kondisi lingkungan yang tidak sesuai. 


\section{Proksimat Daging}

Hasil analisis proksimat daging ikan nila tersaji pada Tabel 2. Penambahan rElGH pada pakan ikan nila meningkatkan kadar protein dalam tubuh ikan nila biru dan Srikandi, namun tidak terjadi pada ikan nila Nirwana.

\section{Description: the crude fiber not detected}

Pemberian rElGH melalui pakan pada penelitian ini diduga menyebabkan terjadinya peningkatan sintesis protein. Seperti yang dilaporkan oleh beberapa peneliti bahwa dengan pemberian rGH dapat meningkatkan sintesis protein dan menurunkan sintesis lemak pada mamalia (Pell et al., 1990; Johnsson et al., 1987) dan menstimulasi anabolisme dalam meningkatkan penggantian dan sintesis protein pada ikan, yang terjadi pada hati dan otot dengan menstimulasi efisiensi dari translasi ribosom melalui peningkatan konsentrasi mRNA dan ribosom (Foster et al., 1991; Herbert et al., 2001). Mekanisme tersebut diduga melalui optimasi pemanfaatan protein sebagai sumber energi untuk pertumbuhan. Selanjutnya, penurunan kadar lemak tubuh pada ikan perlakuan diduga berkaitan dengan aktivitas enzim lipase, sesuai yang dikemukakan oleh Irmawati et al. (2012) bahwa aktivitas enzim lipase ikan gurame yang diberi rGH lebih tinggi dibandingkan dengan ikan kontrol. Kandungan protein yang lebih rendah pada kontrol diduga meningkatnya proses anabolisme dalam tubuh untuk memperbaiki sel-sel yang rusak untuk kelangsungan hidup. Hal tersebut terlihat dari kelangsungan hidup dan pertumbuhan yang lebih rendah pada ikan kontrol terutama pada ikan nila Srikandi dan Nirwana. Walaupun ukuran dan umur ikan, jenis pakan, dan beberapa faktor eksperimental dapat memengaruhi komposisi kimia tubuh; penyebab berbedanya hasil penelitian-penelitian tersebut lebih disebabkan karena perbedaan respons spesies, jenis rGH, dan dosis yang berbeda-beda (Liu et al., 2008).

\section{Uji Tantang Bakteri S. agalactiae}

Pola kematian ikan nila pascainfeksi dengan bakteri S. agalactiae disajikan pada Gambar 5. Kematian ikan nila selama masa infeksi berlanjut hingga masa recovery, data tersaji pada Gambar 6. Ikan nila yang sudah mendapatkan perlakuan rElGH pada pakan menunjukkan ketahanan tubuh yang berbeda ketika diuji tantang dengan bakteri. Kematian kumulatif tertinggi selama satu minggu uji tantang terdapat pada populasi ikan nila biru dan Srikandi kontrol, sedangkan ikan nila Nirwana kontrol memiliki tingkat kematian kumulatif yang rendah dibandingkan ikan nila yang lainnya.

Hasil penghitungan MTD ikan nila akibat infeksi $S$. agalactiae disajikan pada Gambar 7. Ikan biru kontrol memiliki rerata waktu kematian tercepat yaitu 77,87 $\pm 23,31$ jam; sedangkan yang terlama adalah ikan Nirwana kontrol yaitu 217,17 \pm 28,21 jam. Berdasarkan hasil pengukuran rerata waktu kematian dapat diketahui bahwa $S$. agalactiae lebih bersifat kronis yaitu tidak langsung menyebabkan kematian namun menyebabkan perubahan pada fisiologis ikan yang terinfeksi terlebih dahulu, tidak seperti bakteri Vibrio alginolyticus yang memiliki nilai MTD 12-28 jam yang dapat dikategorikan sebagai bakteri akut, dapat menyebabkan kematian secara cepat (Murdjani, 2002).

Infeksi streptococcosis pada ikan nila berlangsung selama dua minggu, pada masa infeksi minggu pertama didapatkan hasil yang berbeda nyata $(\mathrm{P}<0,05)$ antar perlakuan (Gambar 5). Hari pertama pasca uji tantang pada ikan nila biru dan Srikandi kontrol sudah terjadi kematian ikan sebanyak 20\%-25\% per ulangannya. Sedangkan pada perlakuan rElGH, masing-masing strain ikan nila mulai banyak mengalami kematian

Tabel 2. Kadar proksimat daging tiga strain ikan nila diberi pakan mengandung rElGH dan tanpa rElGH (kontrol)

Table 2. Proximate levels of meat three strains of tilapia fed contains rElGH and non-rElGH (control)

\begin{tabular}{lcccc}
\hline \multicolumn{1}{c}{ Perlakuan } & Abu & Protein & Lemak & BETN \\
& Ash & Protein & Fat & NFE (nitrogen free extract) \\
\hline Nila biru rEl GH (Blue tilapia r El GH) & 14.73 & 58.04 & 26.96 & 0.27 \\
Nila biru kontrol (Blue tilapia control) & 13.97 & 56.04 & 29.81 & 0.18 \\
Nila Srikandi rEl GH (Srikandi tilapia r El GH) & 18.27 & 60.37 & 20.21 & 1.14 \\
Nila Srikandi kontrol (Srikandi tilapia control) & 17.82 & 56.85 & 25.08 & 0.24 \\
Nila Nirwana rEl GH (Nirwana tilapia r El GH) & 17.06 & 55.04 & 27.59 & 0.30 \\
Nila Nirwana kontrol (Nirwana tilapia control) & 22.02 & 57.39 & 20.31 & 0.22 \\
\hline
\end{tabular}

Keterangan: Serat kasar tidak terdeteksi 


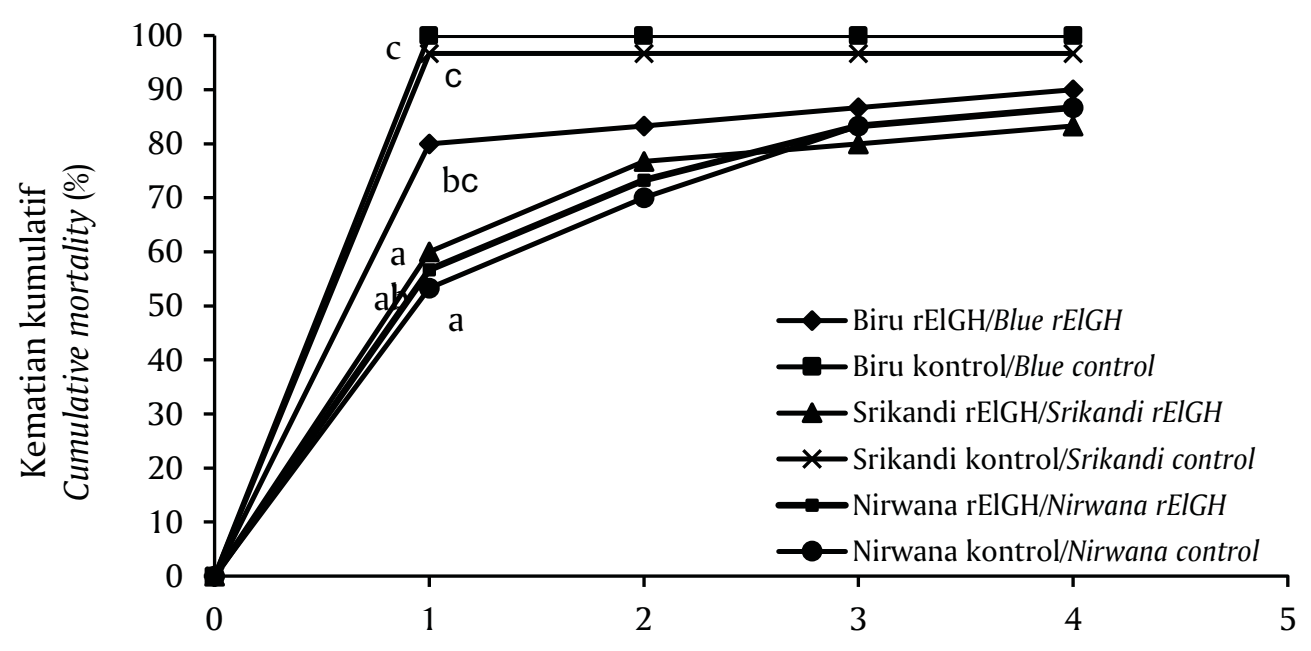

Minggu ke- (Weeks)

Gambar 6. Kematian kumulatif (\%) ikan nila strain biru, Srikandi, dan Nirwana yang diberi pakan mengandung rElGH dan tanpa rElGH (kontrol) yang diuji tantang dengan bakteri S. agalactiae

Figure 6. Cumulative mortality (\%) strain of blue tilapia, Srikandi, and Nirwana are fed contains rElGH and without rElGH (control) were tested challenged with $S$. agalactiae bacteria

setelah tiga hari pasca uji tantang. Hasil penelitian ini mengindikasikan adanya pengaruh rElGH pada peningkatan imunitas tubuh ikan nila pada masa infeksi streptococcosis. Hasil penelitian sebelumnya membuktikan bahwa penambahan rElGH mampu meningkatkan sistem imunitas pada udang vaname (Subaidah et al., 2012) dan kerapu bebek (Antoro, 2014).

Penambahan $\mathrm{r} E \mathrm{GH}$ dosis $2 \mathrm{mg} / \mathrm{kg}$ berpengaruh signifikan pada minggu satu uji tantang, namun tidak

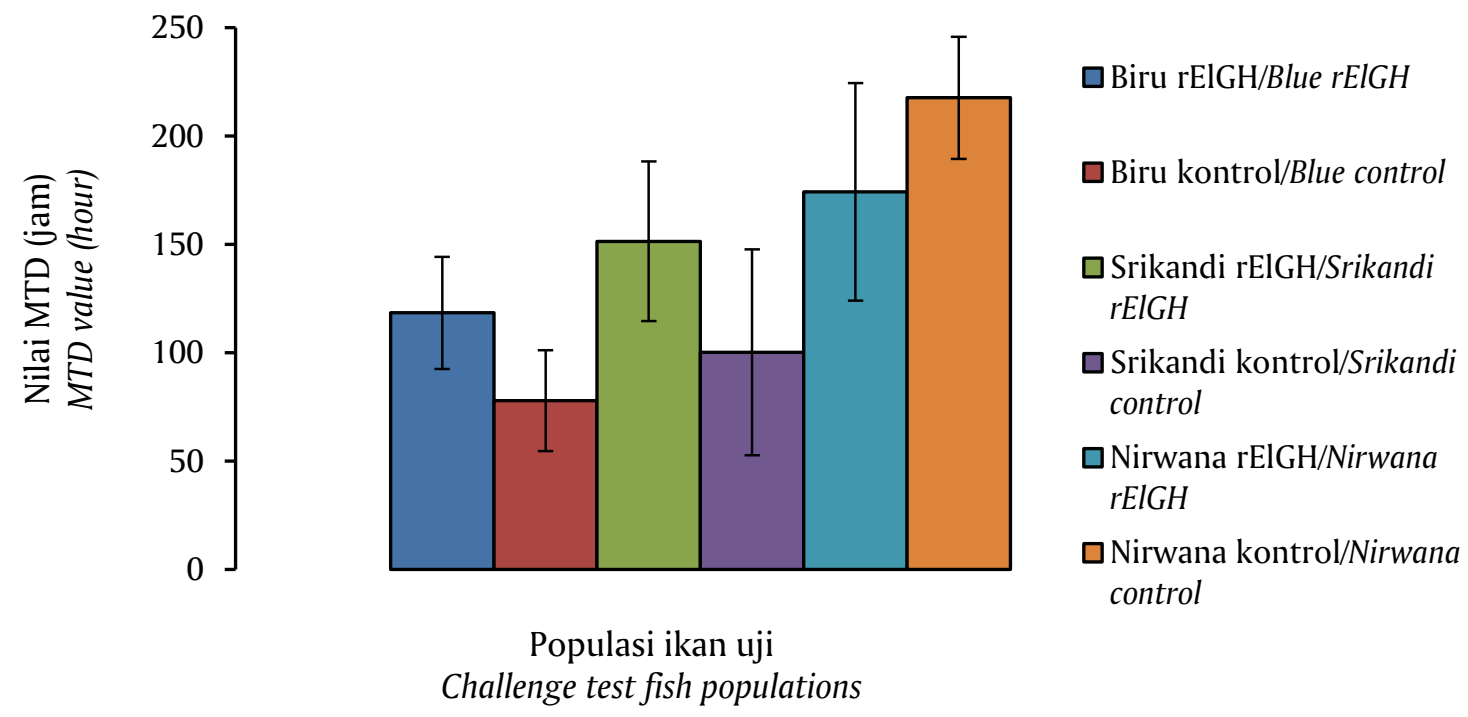

Gambar 7. Nilai MTD (jam) ikan nila strain biru, Srikandi, dan Nirwana yang diberi pakan mengandung rElGH dan tanpa rElGH (kontrol) yang diuji tantang dengan bakteri S. agalactiae selama 30 hari

Figure 7. Value MTD (h) strain of blue tilapia, Srikandi, and Nirwana are fed contains rEIGH and nonrElGH (control) were tested challenged with S. agalactiae bacteria for 30 days 

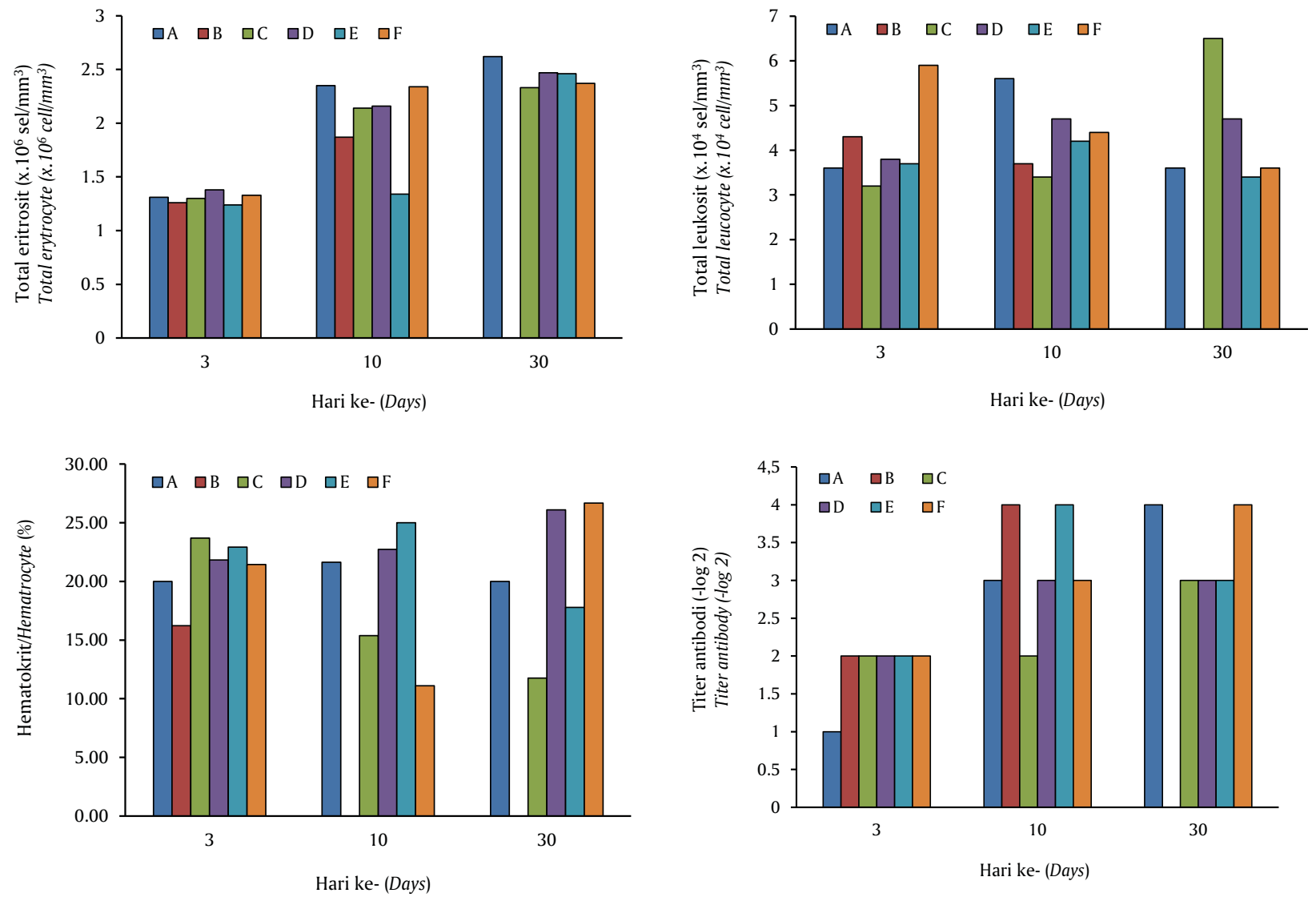

Keterangan: A (biru rElGH); B (biru kontrol); C (Srikandi rElGH); D (Srikandi kontrol); E (Nirwana rElGH); F (Nirwana kontrol) Description: A (biru rElGH); B (blue control); C (Srikandi rElGH); D (Srikandi control); E (Nirwana rElGH); F (Nirwana control)

Gambar 8. Gambaran darah (total eritrosit, total leukosit, hematokrit, dan titer antibodi) hari ke-3, 10, dan 30 pada ikan nila strain biru, Srikandi, dan Nirwana yang diberi pakan mengandung rElGH dan tanpa rElGH (kontrol) yang diuji tantang dengan bakteri S. agalactiae

Figure 8. The blood figure (total erythrocytes, total leukocytes, hematocrit, and antibody titre) 3rd day, 10, and 30 on the strain of blue tilapia, Srikandi, and Nirwana are fed contains rElGH and non-rElGH (control) were tested bacterial challenge with $S$. agalactiae

berlanjut pada minggu ke-2 sampai akhir penelitian akibat tingginya tingkat virulensi $S$. agalactiae yang digunakan pada penelitian ini dengan kematian berkisar $80 \%-100 \%$. Hasil uji statistik diperoleh pemberian $\mathrm{r} E l \mathrm{GH}$ tidak berpengaruh nyata $(\mathrm{P}>0,05)$ pada ikan nila dalam melawan infeksi $S$. agalactiae, akan tetapi strain dan interaksi antara strain dengan pemberian $\mathrm{r} E \mathrm{IGH}_{\mathrm{G}}$ pada ikan nila berpengaruh nyata $(\mathrm{P}<0,05)$ terhadap nilai sintasannya. Hal ini mengindikasikan tingkat ketahanan ikan nila dipengaruhi oleh faktor genetik dari masing-masing strain ikan nila. Sebagai ikan hasil hibridisasi selain memiliki pertumbuhan yang lebih tinggi dari kedua tetuanya, hasil penelitian ini juga mengindikasikan ikan nila srikandi rElGH memiliki ketahanan tubuh yang lebih baik dari tetuanya dengan tingkat kematian terendah yaitu sebesar $83,3 \%$.

\section{Keragaan Hematologi pada Tiga Strain Ikan Nila}

Status kesehatan ikan yang diamati dari gambaran darah (Gambar 8) menjelaskan pada hari ke-3 setelah uji tantang kondisi fisiologi ikan terganggu akibat infeksi bakteri. Kisaran nilai eritrosit, leukosit, hematokrit, dan titer antibodi pada ikan kontrol negatif berturut-turut adalah $1,24-2,74 \times 10^{6} \mathrm{sel} / \mathrm{mm}^{3}$, 2,4-4 x $10^{4} \mathrm{sel} / \mathrm{mm}^{3}, 11 \%-46 \%$, dan $1-2(\log 2)$. Perubahan nilai hematokrit dan leukosit dalam darah terjadi karena adanya proses fisiologis tubuh yang bereaksi terhadap adanya antigen yang masuk, dan ikan sedang mengalami infeksi sehingga tubuh ikan mengantisipasi kondisi tersebut dengan memproduksi leukosit lebih banyak sebagai respons imunitas. Total eritrosit ikan perlakuan meningkat sampai akhir pemeliharaan ikan. Peningkatan total eritrosit 
berkaitan dengan kemampuan ikan dalam memproduksi hemoglobin yang berfungsi mengikat oksigen dan mengedarkan ke seluruh tubuh. Titer antibodi mencerminkan kemampuan tubuh ikan terhadap infeksi bakteri melalui respons imun spesifik. Semakin tinggi nilai titer maka diharapkan kemampuan perlindungan terhadap infeksi juga menjadi tinggi. Nilai antibodi perlakuan berkisar antara 1-4 (log 2). Antibodi yang jumlah dan konsentrasinya lebih banyak dalam serum darah merupakan penangkal serangan agen penyakit yang masuk ke dalam tubuh.

\section{KESIMPULAN}

Pemberian pakan dengan $\mathrm{r} E \mathrm{lGH}$ dosis $2 \mathrm{mg} / \mathrm{kg}$ selama dua minggu mampu meningkatkan performa pertumbuhan dan keragaan hematologi, serta imunitas terhadap infeksi bakteri S. agalactiae pada ikan nila Srikandi. Strain ikan nila sangat memengaruhi efektivitas pemberian rElGH dalam memacu pertumbuhan dan status imunitas.

\section{UCAPAN TERMA KASIH}

Ucapan terima kasih atas bantuan dan dukungan selama penelitian dan penyusunan tulisan ini penulis sampaikan kepada Dr. Imron (Kepala BPPI), tim nila (Sdr. Adam, Lamanto, Ifan, Bisri, Oman, Hari), Diah (Lab. Genetika), Hary Krettiawan, dan Dendi Hidayatullah (mahasiswa pasca IPB), serta semua pihak yang tidak dapat penulis sebutkan satu per satu.

\section{DAFTAR ACUAN}

Acosta, J., Carpio, Y., Besada, V., Morales, R., Sánchez, A., Curbelo, Y., Ayala, J., \& Estrada, M.P. (2008). Recombinant truncated tilapia growth hormone enhances growth and innate immunity in tilapia fry Oreochromis sp. Gen. Comp. Encocrinol., 157, 4957.

Anderson, D.P. (1974). Fish immunology. Hongkong: TFH Publication Ltd. 182 pp.

Antoro, S. (2014). Performa pertumbuhan, komposisi biokimia, imunitas bawaan dan histologi benih ikan kerapu bebek setelah perlakuan hormon pertumbuhan rekombinan. Disertasi. Institut Pertanian Bogor.

Blaxhall, P.C., \& Daisley, K.W. (1973). Routine haematological methods for use with fish blood. J. Fish Biology, 5, 577-581.

Foster, A.R., Houlhan, D.F., Gray, C., Medalem, F., Fauconneau, B., Kaushik, S.J., \& LeBail, P.Y. (1991). The effect of ovine growth hormone on protein turnover in rainbow trout. Gen. Comp. Endocrinol., 82, 111-120.
Handoyo, B., Alimuddin, \& Utomo, N.B.P. (2012). Pertumbuhan, konversi, dan retensi pakan, dan proksimat tubuh benih ikan sidat yang diberi hormon pertumbuhan rekombinan ikan kerapu kertang melalui perendaman. J. Akuat. Indonesia, 11(2), 132-140.

Hardiantho, D., Alimuddin, Prasetyo, A.E., Yanti, D.H., \& Sumantadinata, K. (2012). Performa benih ikan nila diberi pakan mengandung hormon pertumbuhan rekombinan ikan mas dengan dosis berbeda. J. Akua. Indonesia, 11(1), 17-22.

Herbert, N.A., Armstrong, J.D., \& Björnsson, B.T. (2001). Evidence that growth hormone-induced elevation in routine metabolism of juvenile Atlantic salmon is a result of increased spontaneous activity. J. Fish Biol., 59, 754-757.

Hertz, Y., Tachelet, A., Madar, Z., \& Gertler, A. (1991). Absorption of bioactive human growth hormone after oral administration in the common carp and its enhancement by deoxycholate.J. Comp. Physiol., $161,159-163$.

Inglis, V., Roberts, R.J., \& Bromage, N.R. (1993). Streptococcal infections. In-Bacterial diseases of fish. Halsted. New York, p. 196-197.

Irmawati, Alimuddin, Junior, M.Z., Suprayudi, M.A., \& Wahyudi, A.T. (2012). Peningkatan laju pertumbuhan benih ikan gurami Osphronemus goramy, Lac yang direndam dalam air yang mengandung hormon pertumbuhan ikan mas. J. Iktio. Indonesia, 12(1), 13-23.

Iwana, G.K., \& Nakanishi, T. (1996). The fish immune system, organism, pathogen and environment. Academic Press. London, 380 pp.

Jentoft, S., Topp, N., Seeliger, M., Malison, J.A., Barry, T.P., Held, J.A., Roberts, S., \& Goetz, F. (2005). Lack of growth enhancement by exogenous growth hormone treatment in yellow perch (Perca flavescens) in four separate experiments. Aquaculture, 250, 471-479.

Johnsson, I.D., Hathom, D.J., Wilde, R.M., Teacher, T.T., \& Butler-Hogg, B.W. (1987). The effect of dose and method of administration of biosynthetic bovine somatotropin on live-weight gain, carcasss composition and wool growth in young lambs. Anim. Prod., 44, 405-414.

Kamiso, H.N. (2001). Immunologi dan Vaksinasi pada Ikan. DUE Project. Fakultas Perikanan. Universitas Riau, Pekanbaru.

Leedom, T.A., Uchida, K., Yada, T., Richman III, N.H., Byatt, J.C., Collier, R.J., Hirano, T., \& Grau, E.G. (2002). Recombinant bovine growth hormone treatment of tilapia: growth response, metabolic clearance, receptor binding and immunoglobulin production. Aquaculture, 207, 359-380. 
Le Bail, P.-Y., Perez-Sanchez, J., Yao, K., \& Maisse, G. (1993). Effect of GH treatment on salmonid growth: study of the variability of response. Coastal and Estuarine Studies Aquaculture: Fundamental and Applied Research, 43, 173-197.

Liu, S., Zhang, X., Zang, X., Liu, B., Arunakumara, K.K.I.U., Xu, D., \& Zhang, X. (2008). Growth, feed efficiency, body muscle composition, and histology of flounder Paralichthys olivaceus fed GH transgenic Synechocystis. Aquaculture, 277, 78-82.

Mata, A.I., Blanco, M.M., Dominguez, L., FernandezGarayzabal, J.F., \& Gibello, A. (2003). Development of a PCR assay for Streptococcus iniae based on the lactate oxidase $($ lctO) gene with potential diagnostic value. Vet. Microbiol., 46, 225-229.

Muhammad. (2014). Respons pertumbuhan ikan nila merah yang diberi pakan mengandung hormon pertumbuhan rekombinan pada dosis berbeda. Disertasi. Institut Pertanian Bogor.

Murdjani, M. (2002). Identifikasi dan patologi bakteri Vibrio alginolyticus pada ikan kerapu tikus Cromileptes altivelis. Disertasi. Program Pasca Sarjana, Universitas Brawijaya.

Pell, J.M., Elock, C., Harding, R.L., Morrell, D.J., Simmonds, A.D., \& Wallis, M. (1990). Growth, body composition, hormonal and metabolic status in lambs treated long-term with growth hormone. Br. J. Nutr., 63, 431-445.

Plumb, J.A. (1999). Health maintenance and principal microbial disease of cultured fishes. Iowa State University Press Ames.
Putra, H.G.P. (2010). Pertumbuahan dan kelangsungan hidup benih ikan gurame yang diberi protein rekombinan HP melalui perendaman dengan dosis berbeda. Skripsi. Departemen Budidaya Perairan, Fakultas Perikanan dan Ilmu Kelautan, Institut Pertanian Bogor.

Safir, M. (2012). Respons benih ikan gurami Osphronemus goramy yang diberi hormon pertumbuhan rekombinan melalui oral pada dosis berbeda. Tesis. Institut Pertanian Bogor.

Subaidah, S., Carman, O., Sumantadinata, K., Sukenda, \& Alimuddin. (2012). Respons pertumbuhan dan ekspresi gen udang vaname Litopenaeus vannamei setelah direndam dalam larutan hormon pertumbuhan rekombinan ikan kerapu kertang.J. Ris. Akuakultur, 7(3), 337-352.

Takeuchi, T. (1988). Laboratory work, chemical evaluation of dietry nutrients. In Fish Nutrition and Mariculture. Watanabe, T. (Ed.). Department of Aquatic Bioscience, Tokyo University of Fisheries. Tokyo, p. 179-225.

Yanong, P.E.R., \& Francis-Floyd, R. (2006). Streptococcal infections of ûsh. Univ. Fla. IFAS Ext., 57, 16.

Yin, L.K. (2004). Current trends in the study of bacterial and viral fish and shrimp diseases. World Scientific Publishing Co., Singapore.

Zonneveld, N., Huisman, E.A., \& Boon, J.H. (1991). Prinsip-prinsip budidaya ikan. Gramedia Pustaka Utama. Jakarta. 